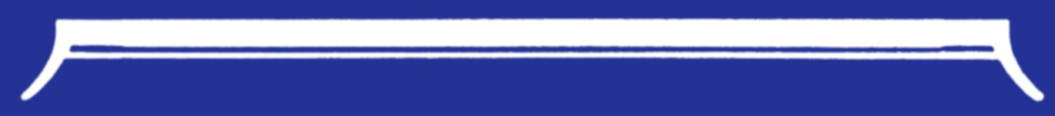

\title{
SOUTHERN JOURNAL OF
}

\section{AGRICULTURAL ECONOMICS}

\author{
$m i$ \\ Volume 13, Number 2 \\ December, 1981
}

Published by

Southern Agricultural Economics Assoclation 


\title{
SOUTHERN JOURNAL OF AGRICULTURAL ECONOMICS
}

\author{
Volume 13, Number 2 \\ December, 1981
}

Copyright (C) 1981 by the Southern Agricultural Economics Association

\section{Editorial Council}

LEO J. GUEDRY, ALVIN SCHUPP and KENNETH PAXTON, Louisiana State University, Editors W. LANNY BATEMAN, Mississippi State University ERNEST BENTLEY, Virginia Polytechnic Institute and

State University KENNETH CLAYTON, ESS, USDA

JAMES E. EPPERSON, Georgia Experiment Station DAVID E. ERVIN, University of Missouri-Columbia DEWITT JONES, Southern University

LINDA K. LEE, Oklahoma State University

DANIEL L. MCLEMORE, University of Tennessee

LYNN W. ROBBINS, University of Kentucky

FRED B. SAUNDERS, University of Georgia

ALLEN SHIAU, Chase Econometrics

JOHN R. STOLL, Texas A\&M University

GREGORY M. SULLIVAN, Auburn University

RONALD W. WARD, University of Florida

GARY J. WELLS, Clemson University

\section{Editorial Policy}

The purpose of the Journal is to provide a forum for creative and scholarly work in agricultural economics and related areas. Contributions on methodology and applications in business, extension, research and teaching phases of agricultural economics are encouraged. Preference will be given to articles addressing problems and issues of concern in the southern region of the United States. Only articles recommended by the Editorial Council are accepted for publication.

The Editorial Council encourages constructive criticism of Journal articles and will publish accepted comments and replies.

\section{Editorial Staff}

Ruth Hubert, Copy Editor

\section{Executive Committee}

PRESIDENT

PRESIDENT-ELECT

PAST-PRESIDENT

FIRST VICE-PRESIDENT

SECOND VICE-PRESIDENT

SECRETARY-TREASURER
Bobby R. Eddleman, Mississippi State University Robert Raunikar, Georgia Experiment Station ... Garnett Bradford, University of Kentucky Gerald A. Doeksen, Oklahoma State University Jerry G. West, University of Missouri-Columbia . H. Evan Drummond, University of Florida

Southern Journal of Agricultural Economics is published in July and December by the Southern Agricultural Economics Association.

Membership in the SAEA, consisting of persons and organizations having a professional interest in agricultural economics, includes subscription to the Journal. Regular membership dues are $\$ 10$. Junior membership dues are $\$ 5$.

The annual subscription rate for libraries and other institutions is $\$ 15$. Single copies of current issues are available to individuals at a price of $\$ 5$.

Please address all subscription, membership and change of address requests to H. Evan Drummond, Food and Resource Economics Department, McCarty Hall, University of Florida, Gainesville, Florida 32611. 


\section{SOUTHERN JOURNAL OF}

\section{AGRICULTURAL ECONOMICS}

Volume 13, Number 2

December, 1981

Published by

Southern Agricultural Economics Association 


\section{CONTENTS}

Economics of Alternative Beef Cattle Genotype

and Management/Marketing Systems

Kenneth W. Stokes

Donald E. Farris

Thomas C. Cartwright

Effectiveness of Competition to Limit Rail

Rate Increases under Deregulation: The

Case of Wheat Exports from the Southern

Plains

Stephen Fuller and C. V. Shanmugham

Modeling the Effects of the Food Stamp Program

on Participating Households' Purchases:

An Empirical Application

Chung L. Huang

Stanley M. Fletcher

Robert Raunikar

Patenting Life Forms: Issues Surrounding the

Plant Variety Protection Act

Barbara A. Claffey

Adaptive Planning Under Price Uncertainty

in Pork Production

Ronald L. Plain and Joseph E. Williams

Economic Impact of Integrated Pest Management

Strategies for Cotton Production in the

Coastal Bend Region of Texas

Sharif M. Masud

Ronald D. Lacewell

C. Robert Taylor

John H. Benedict

Lawrence A. Lippke

Energy Efficiency in Food Processing in the

Southern Region

Josef M. Broder and John T. Booth

Part-Time Farming: Productivity and Some

Implications of Off-Farm Work by Farmers

Surendra P. Singh and Handy Williamson, Jr.

Generic Advertising, FOB Promotion, and FOB

Revenue: A Case Study of the Florida

Grapefruit Juice Industry

Jong-Ying Lee 
Pest Information Markets and Integrated Pest

Management

Michael E. Wetzstein .

Economic Evaluation of an Alternative

Marketing System for Feeder Cattle

in Alabama

Gregory M. Sullivan and Daniel A. Linton

Wood Fuel: An Alternative Energy Source for

Agribusiness and Industry

Glenn C. W. Ames and Harold O. Baxter .

Transportation Alternatives in Rural Communities:

A Feasibility Analysis

Lynn L. Reinschmiedt and Steven W. Murray

A Tobit Model of the Demand for Farmland

Rod F. Ziemer and Fred C. White

Analyzing the Economic Impact of National Beef

Import Level Changes on the Virginia Beef

and Pork Sectors

Kenneth Baum

Ali N. Safyurtlu

Wayne Purcell

A Note on the Specification of Wage Rates in Cost-

Push Models of Food Price Determination

Mike Belongia

A Method for Estimating the Value of Water Among

Sectors of a Regional Economy

Mark S. Henry and Ernie Bowen

Interaction of Japanese Rice and Wheat Policy

and the Impact on Trade

Cathy L. Jabara

The Effect of Increasing Transportation Costs on

Florida's Cattle Feeding Industry: An

Extension Application

James R. Simpson and Forrest E. Stegelin

Areas of Critical State Concern: Florida's

Experience with the Green Swamp

Clyde Kiker and Gary D. Lynne

\section{COMMENTS AND REPLIES}

Comment: A Theoretical Framework for Analyzing

Social Costs of the Tobacco Program

Earl A. Stennis and M. J. Fuller

Reply: A Theoretical Framework for Analyzing

Social Costs of the Tobacco Program

Ruth T. Johnson and B. R. McManus

Colleagues Who Assisted the Editorial Council During 1981 